\title{
The influence of cigarette smoke inhalation on bone density. $A$ radiographic study in rats
}

\section{Influência da fumaça de cigarro na densidade óssea. Estudo radiográfico em ratos}

\author{
João Batista César-Neto* \\ Bruno Braga Benatti* \\ Flávio Ricardo Manzi** \\ Enilson Antônio Sallum*** \\ Antônio Wilson Sallum**** \\ Francisco Humberto Nociti Junior***
}

\begin{abstract}
The aim of this study was to evaluate the influence of cigarette smoke inhalation (CSI) and its cessation on tibiae bone quality. Forty-one male Wistar rats were randomly assigned to one of the following groups: Group 1 - control $(\mathrm{n}=14)$, Group $2-3$ months of CSI and 2 months without exposure to CSI $(\mathrm{n}=12)$, and Group 3-5 months of CSI $(n=15)$. At the end of the experimental period, the animals were sacrificed, the tibiae removed and immediately radiographed for photodensitometric analysis. The results showed that continuous exposure to cigarette smoke promoted a significantly reduced bone density $(\mathrm{p}<0.05)(3.22 \mathrm{~mm} \mathrm{Al} \mathrm{eq} \pm 0.58 ; 2.93$ $\mathrm{mm} \mathrm{Al} \mathrm{eq} \pm 0.45 ; 1.86 \mathrm{~mm} \mathrm{Al} \mathrm{eq} \pm 0.35$; for groups 1,2 and 3 , respectively). Similar levels of bone density were observed for the control and cessation groups (groups 1 and $2-p>0.05$ ). Thus, within the limits of the present study, it can be concluded that CSI may affect tibiae bone quality, and CSI cessation results in a return towards the level of the control group.
\end{abstract}

DESCRIPTORS: Smoking; Bone density; Rats, Wistar.

\begin{abstract}
RESUMO: O objetivo deste estudo foi avaliar a influência da inalação da fumaça de cigarro (IFC) e o efeito de sua interrupção na qualidade óssea da tíbia. Quarenta e um ratos Wistar machos foram aleatoriamente designados a um dos seguintes grupos: Grupo 1 - controle $(\mathrm{n}=14)$, Grupo $2-3$ meses de IFC e 2 meses sem exposição à fumaça $(n=12)$ e Grupo $3-5$ meses de IFC $(n=15)$. Ao final do período experimental, os animais foram sacrificados, as tíbias removidas e imediatamente radiografadas para a análise fotodensitométrica. Os resultados mostraram que a exposição contínua à fumaça de cigarro promoveu uma significante redução na densidade óssea $(p<0,05)(3,22$ $\mathrm{mm} \mathrm{Al} \mathrm{eq} \pm 0,58,2,93 \mathrm{~mm} \mathrm{Al} \mathrm{eq} \pm 0,45,1,86 \mathrm{~mm} \mathrm{Al} \mathrm{eq} \pm 0,35$, para os grupos 1,2 e 3 , respectivamente). Niveis semelhantes de densidade óssea foram observados nos grupos controle e interrupção (grupos 1 e 2 - p > 0,05). Portanto, dentro dos limites do presente estudo, pode-se concluir que a IFC pode influenciar a qualidade óssea da tíbia e que a interrupção da inalação parece reverter esse efeito negativo resultando numa densidade óssea semelhante à do grupo controle.
\end{abstract}

DESCRITORES: Tabagismo; Densidade óssea; Ratos Wistar.

\section{INTRODUCTION}

Over the past 20 years, endosseous titanium implants have proven to be amongst the most predictable treatments in oral health care. Quality of life assessments show implant-retained prosthesis to be a highly satisfactory method of tooth replacement $t^{1,18}$. However, some systemic conditions have been correlated with higher rates of failure ${ }^{8}$. Among these conditions, smoking is one of the factors most discussed in relation to implant failure ${ }^{3,4,6,8,18}$.
Studies have provided evidence that the impact of tobacco smoking on tissues may be reversible. Liede et al. ${ }^{17}$ (1999) observed that periodontal status and mucosal health were better in individuals who had quit smoking when compared with current smokers. Gingival microcirculation has also been shown to recover its normal function on the early stages of smoking cessation ${ }^{19}$, and the changes in the inflammatory response of the periodontium can also be reversible upon

\footnotetext{
*PhD Students, Division of Periodontics; **PhD Student, Division of Radiology; ***Associate Professors, Division of Periodontics; ${ }^{* * * *}$ Chairman, Division of Periodontics - School of Dentistry of Piracicaba, State University of Campinas.
} 
César-Neto JB, Benatti BB, Manzi FR, Sallum EA, Sallum AW, Nociti Junior FH. The influence of cigarette smoke inhalation on bone density. A radiographic study in rats. Braz Oral Res 2005;19(1):47-51.

quitting smoking ${ }^{20}$. Bain, Moy $^{4}$ (1994) clinically examined the influence of smoking cessation on implant outcome, and did not find differences in the failure rate between non-smoking controls and the smokers who had quit.

The reason of a higher rate of implant failure among smokers is not fully elucidated. One possibility may be the harmful effect of smoking on bone density, since poor bone quality is a factor related to implant failure ${ }^{12}$. A clinical study has already suggested that a higher incidence of poor bone quality is observed in smokers ${ }^{4}$. Although most of the animal studies conducted have not reported a correlation between nicotine administration and lower bone density ${ }^{2,9,24,25}$, nicotine is just one of the potentially toxic compounds of cigarette smoke. Still, the number of studies evaluating the effect of cigarette smoke as a whole and smoking cessation on bone is limited. Thus, based on the clinical relevance of this subject, and on the limited number of studies available, this study is proposed to investigate the influence of cigarette smoke inhalation and its cessation on bone density.

\section{MATERIALS AND METHODS}

\section{Animals}

Forty-one male Wistar rats (300-400 g) were used. The animals were kept in plastic cages with food and water ad libitum. The protocol was approved by the State University of Campinas Institutional Animal Care and Use Committee.

\section{Experimental design}

The animals were randomly assigned to one of the following groups: Group 1 - control: animals that were not exposed to cigarette smoke inhalation (CSI) at any time during the experimental period ( $\mathrm{n}=14$ ), Group $2-3$ months of CSI followed by 2 months without exposure $(\mathrm{n}=12)$ and Group 3 CSI during 5 months $(\mathrm{n}=15)$ (Figure 1).

The animals of groups 2 and 3 were intermittently housed in an animal cigarette smoke exposure chamber as previously described ${ }^{6,21,22}$. Briefly, the device consisted of a $45 \times 25 \times 20 \mathrm{~cm}^{3}$ clear acrylic chamber, an air-pump and two inflow/outflow tubes. Five animals were housed in the chamber at the same time, and the cigarette smoke of 10 cigarettes, containing $1.3 \mathrm{mg}$ of nicotine, $16.5 \mathrm{mg}$ of tar, and $15.2 \mathrm{mg}$ of carbon monoxide each, was pumped into the chamber. Thus, the animals were exposed to cigarette smoke that contaminated the air for 8 minutes, 3 times daily until they were sacrificed. The animals of group 1 were not exposed to cigarette smoke at any time. The serum levels of nicotine and cotinine obtained by using this model have been previously reported ${ }^{6}$.

\section{Radiographic analysis}

Immediately after the sacrifice, the tibiae of the animals were removed and radiographed using an X-ray unit (GE 1000, General Electric Company, Milwaukee, Wisconsin, USA) with an exposure time of 0.3 seconds $(60 \mathrm{kVp}, 10 \mathrm{~mA})$ and $31 \mathrm{x} 41 \mathrm{~mm}$ radiographic film (Insight Film, Eastman Kodak, Rochester, NY, USA). A reference radiograph of an aluminum step-wedge (Nuclear Associates, Carle Place, NY, USA) was also taken using the same apparatus and exposure time. The films were developed in an automatic processing machine (Gendex GXP Dental X-Ray Processor, Des Plaines, IL, USA). The total length of the tibiae was measured

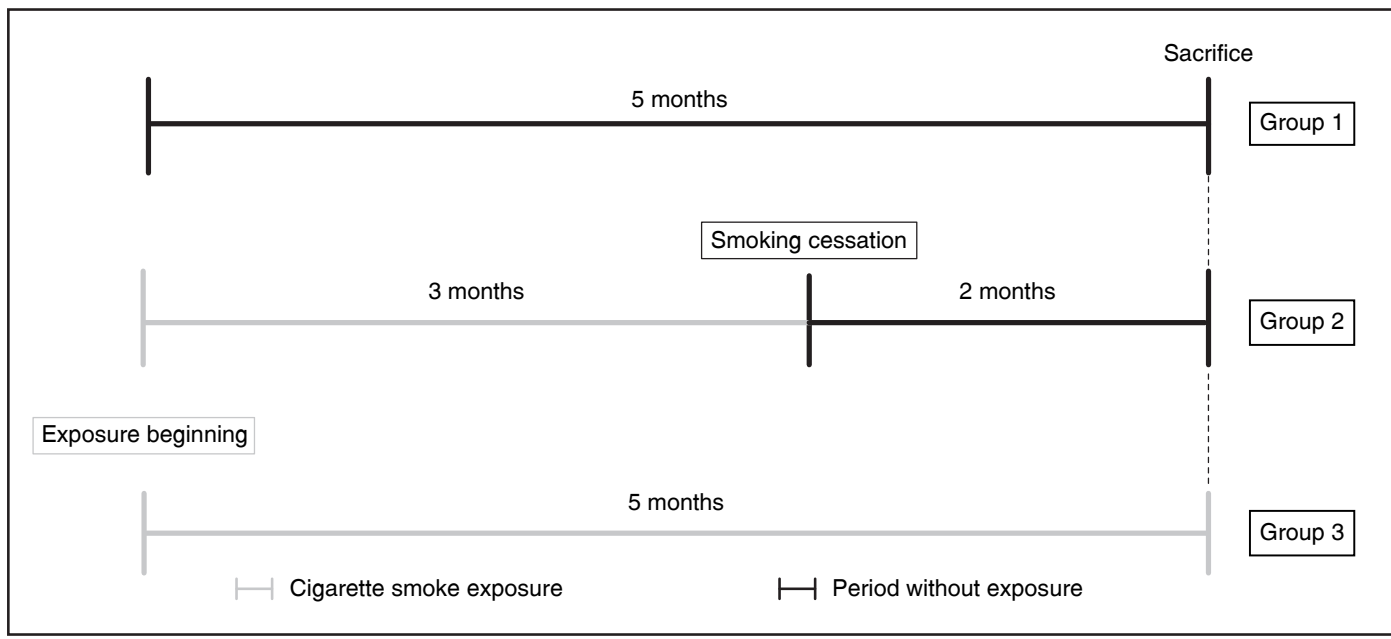

FIGURE 1 - Schematic illustration of the experimental design. 
César-Neto JB, Benatti BB, Manzi FR, Sallum EA, Sallum AW, Nociti Junior FH. The influence of cigarette smoke inhalation on bone density. A radiographic study in rats. Braz Oral Res 2005;19(1):47-51.

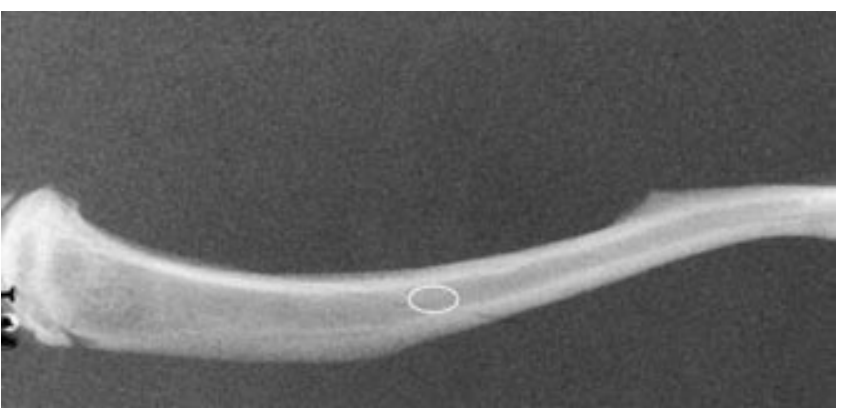

FIGURE 2 - Radiographic image illustrating the tibiae area where photodensitometric measurements were performed.

and the mean point was determined as a reference for photodensitometric analysis (MRA Equipamentos Eletrônicos, Ribeirão Preto, SP, Brazil). A blinded examiner performed five measurements, in order to scan the bone area between the 2 corticals at the level of the previously determined reference point. Figure 2 illustrates the analyzed area. The measurement of bone density was compared with the step-wedge standard to compensate for processing variations and to provide a unit for quantifying bone density, which was expressed in millimeters of aluminum equivalence ( $\mathrm{mm} \mathrm{Al} \mathrm{eq).}$

\section{Statistical analysis}

Mean values of radiographic optical density were determined for each group and compared statistically using one-way analysis of variance (ANOVA) $(\alpha=0.05)$. Pairwise multiple comparisons were carried out by the Tukey's test ( $\alpha=0.05)$ in case the ANOVA test showed significant differences.

\section{RESULTS}

The results showed that continuous exposure to cigarette smoke (group 3) promoted a significantly reduced bone density $(\mathrm{p}<0.05)$ when compared to control and cessation groups ( 1 and 2 , respectively) (3.22 $\mathrm{mm} \mathrm{Al} \mathrm{eq} \pm 0.58 ; 2.93 \mathrm{~mm} \mathrm{Al}$ eq $\pm 0.45 ; 1.86 \mathrm{~mm} \mathrm{Al} \mathrm{eq} \pm 0.35$; for groups 1,2 and 3, respectively). Similar levels of bone density were observed for cessation and control groups $(p>0.05)$. Graph 1 illustrates the results described above.

\section{DISCUSSION}

The mechanism by which smoking influences the success rate of titanium implants is still un-

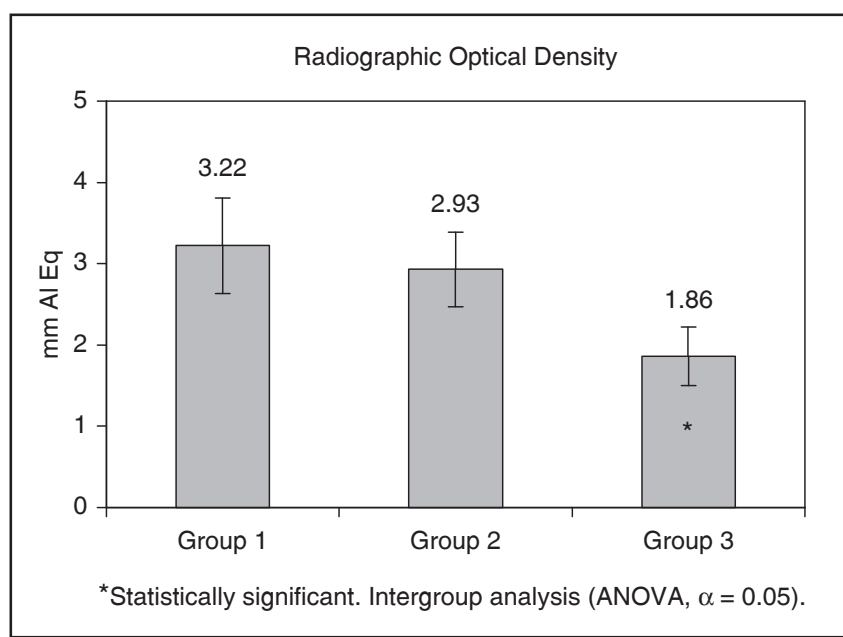

GRAPH 1 - Mean and standard deviation of tibiae bone density, expressed in millimeters of aluminum equivalence ( $\mathrm{mm} \mathrm{Al} \mathrm{eq),} \mathrm{according} \mathrm{to} \mathrm{each} \mathrm{group.}$

clear. The hypothesis that cigarette smoke inhalation would have an influence on the degree of boneto-implant contact and bone filling of the implant threads (parameters evaluated in newly formed bone) was tested in a series of studies of our laboratory ${ }^{6,21,22}$. In general, these studies concluded that CSI has a negative impact on both parameters related to the newly formed bone around implants and nicotine seems to partially contribute to such an effect. Interestingly, a decreased proportion of mineralized tissue in the pre-existing bone adjacent to the implant in the animals submitted to CSI was also observed ${ }^{6}$. This result has brought up the question about a possible effect of CSI on pre-existing bone. Thus, the present investigation was designed to better elucidate this hypothesis, since, in previous studies, it was not possible to exclude an influence of the healing process adjacent to the pre-existing bone. The result of this study showed that CSI significantly reduced bone density and is in agreement with our previous results ${ }^{6,21,22}$ confirming the hypothesis that CSI affects bone metabolism not only in healing areas but also in areas of pre-existing bone.

Within the limits of our knowledge, this is the first study that investigated in an animal model the influence of CSI on bone quality of an area not adjacent to titanium implants. Despite smoking being considered one of the main risk factors to osteoporosis, most of the animal studies yet conducted have not reported a correlation between nicotine (one of the main compounds of cigarette smoke) administration and lower bone density $2,9,24,25$. A previous study of ours also reported that nicotine 
César-Neto JB, Benatti BB, Manzi FR, Sallum EA, Sallum AW, Nociti Junior FH. The influence of cigarette smoke inhalation on bone density. A radiographic study in rats. Braz Oral Res 2005;19(1):47-51.

did not present a negative impact on bone healing around implants inserted in tibiae of rabbits ${ }^{24}$. On the other hand, the result of the present study showed that cigarette smoke, as a whole, presented a negative impact on bone quality and is in line with the hypothesis suggested by Akhter et al. ${ }^{2}$ (2003), that tobacco agents other than nicotine are responsible for the decreased bone density and increased fracture risk observed in smokers.

One of the most widely employed techniques to assess bone density in humans is dual energy Xray absormetry (DEXA). However, DEXA technique in the mandible is difficult and expensive, and it can only be used in edentulous areas ${ }^{14}$. Photodensitometry of periapical and panoramic radiographs has been utilized to estimate mandibular bone $\operatorname{mass}^{14,15,16}$. A significant correlation between skeletal bone mineral density and alveolar bone mass, determined by a photodensitometer, has been reported $^{11,14,16}$. Photodensitometric measurements were also used to compare mandibular bone differences between normal and osteoporotic women ${ }^{15}$. A recent study reported that the sensitivity of DEXA measurements is unsuitable when assessing small bone samples in mice ${ }^{7}$. Therefore, based on this body of evidence, the use of a photodensitometer to assess bone mass may be considered a suitable method to evaluate bone changes in areas where DEXA is not indicated, like bone samples of small animals.

The reversibility of the effects of cigarette consumption has been studied in both medicine and dentistry. A meta-analysis study demonstrated that current smokers presented a significantly reduced bone mass when compared to former and never smokers ${ }^{27}$ and that former smokers presented bone mass that is intermediate or similar to that of never smokers ${ }^{10,27}$. They additionally reported that smoking has a dose-dependent effect on bone loss, which increases fracture risk, and that smoking cessation may present a beneficial effect $^{27}$. The reversibility of smoking effects has also been investigated in dentistry. In vitro studies observed a reversible condition promoted by cigarette compounds (i.e. nicotine, acrolein and acetaldehyde) on periodontal cells ${ }^{5,23}$. Smoking cessation also exerted a beneficial effect on periodontal risk, which decreased with the number of years since quitting ${ }^{26}$. A prospective study over 20 years showed that patients who stopped smoking lost significantly less marginal bone than current smokers ${ }^{13}$. In the implant field, very limited information is available with respect to the reversibility of the effects of smoking on implant outcome. Bain, Moy $^{4}$ (1994) were the first to report that a smoking cessation protocol would improve the success rates of osseointegration in smokers who followed it. The results of the present investigation are in agreement with the studies that showed a reversible condition promoted by cigarette consumption, and support the clinical concept that the effect of cigarette consumption on bone may be reversible.

During the early time of implant procedure development, implant failure was generally attributed to poor surgical technique (infection, overheating of bone and over-instrumentation), poor prosthetic design or management, or patient-related factors (limited available bone, poor oral hygiene and occlusal overload). These findings were largely based on clinical observation, extrapolation from failures in tooth-supported prostheses and dogma. But some studies began to correlate systemic conditions with higher rates of failure ${ }^{3,4,6,8,18}$. Now, smoking has been one of the factors often discussed in relation to decreased success rates of dental implants. Our findings suggest that smoking may affect bone quality, and that smoking cessation may revert the tobacco harmful effect on bone. However, it is not possible to establish a direct correlation between animal findings and a clinical situation, due to the differences between humans and rats and the frequency of smoke administration used in this study. Accordingly, the hypothesis generated by the present study should be clinically evaluated since bone quality is critical for implant success ${ }^{12}$. Once the clinical relevance of the present hypothesis is confirmed, recommendations regarding smoking cessation should be considered to form part of the implant patient approach. Further studies should still be performed in order to determine the time necessary for bone density to recover its normal level after smoking cessation.

\section{CONCLUSION}

Within the limits of the present study, it can be concluded that smoking may affect tibiae bone density, and CSI cessation exerts a beneficial effect on bone quality promoting a return towards the level of the control group.

\section{ACKNOWLEDGMENTS}

The authors gratefully thank the State of São Paulo Research Foundation (FAPESP, Brazil, 02/08554-0) and the National Council for Scientific and Technological Development (304464/03$1, \mathrm{CNPq}$, Brazil), which financially supported Dr. César-Neto and Dr. Nociti-Jr. 
César-Neto JB, Benatti BB, Manzi FR, Sallum EA, Sallum AW, Nociti Junior FH. The influence of cigarette smoke inhalation on bone density. A radiographic study in rats. Braz Oral Res 2005;19(1):47-51.

\section{REFERENCES}

1. Adell R, Eriksson B, Lekholm U, Branemark PI, Jemt T. Long-term follow-up study of osseointegrated implants in the treatment of totally edentulous jaws. Int J Oral Maxillofac Implants 1990;5:347-9.

2. Akhter MP, Iwaniec UT, Haynatzki GR, Fung YK, Cullen DM, Recker RR. Effects of nicotine on bone mass and strength in aged female rats. J Orthop Res 2003;21:14-9.

3. Bain CA. Smoking and implant failure - benefits of a smoking cessation protocol. Int J Oral Maxillofac Implants 1996;11:756-9.

4. Bain CA, Moy PK. The influence of smoking on bone quality and implant failure [abstract]. Int J Oral Maxillofac Implants 1994;9:123.

5. Cattaneo V, Cetta G, Rota C, Vezzoni F, Rota MT, Gallanti A, et al. Volatile components of cigarette smoke: effect of acrolein and acetaldehyde on human gingival fibroblasts in vitro. J Periodontol 2000;71:425-32.

6. César-Neto JB, Duarte PM, Sallum EA, Barbieri D, Moreno Jr H, Nociti Jr FH. A comparative study on the effect of nicotine administration and cigarette smoke inhalation on bone healing around titanium implants. J Periodontol 2003;74:1454-9.

7. Dickson GR, Luczak M, Wlodarski KH. The limitation of DEXA analysis for bone mass determination in mice. Folia Biol (Krakow) 2004;52(1-2):125-9.

8. Esposito M, Hirsch JM, Lekholm U, Thomsen P. Biological factors contributing to failures of osseointegrated oral implants (II). Etiopathogenesis. Eur J Oral Sci 1998;106:721-64.

9. Fung YK, Iwaniec U, Cullen DM, Akhter MP, Haven MC, Timmins P. Long-term effects of nicotine on bone and calciotropic hormones in adult female rats. Pharmacol Toxicol 1999;85:181-7.

10. Hollenbach KA, Barrett-Connor E, Edelstein SL, Holbrook T. Cigarette smoking and bone mineral density in older men and women. Am J Public Health 1993;83:1265-70.

11. Jacobs R, Ghyselen J, Koninckx P, van Steenberghe D. Long-term bone mass evaluation of mandible and lumbar spine in a group of women receiving hormone replacement therapy. Eur J Oral Sci 1996;104(1):10-6.

12. Jaffin RA, Berman CL. The excessive loss of Branemark fixtures in type IV bone: a 5-year analysis. J Periodontol 1991;62(1):2-4.

13. Jansson L, Lavstedt S. Influence of smoking on marginal bone loss and tooth loss - a prospective study over 20 years. J Clin Periodontol 2002;29:750-6.

14. Jonasson G, Bankvall G, Kiliaridis S. Estimation of skeletal bone mineral density by means of the trabecular pattern of the alveolar bone, its interdental thickness, and the bone mass of the mandible. Oral Surg Oral Med Oral Pathol Oral Radiol Endod 2001;92(3):346-52.

15. Kribbs PJ. Comparison of mandibular bone in normal and osteoporotic women. J Prosthet Dent 1990;63(2):218-22.

16. Kribbs PJ, Chesnut $3^{\text {rd }} \mathrm{CH}$, Ott SM, Kilcoyne RF. Relationships between mandibular and skeletal bone in an osteoporotic population. J Prosthet Dent 1989;62(6):703-7.

17. Liede KE, Haukka JK, Hietanen JH, Mattila MH, Ron$\mathrm{ka} \mathrm{H}$, Sorsa T. The association between smoking cessation and periodontal status and salivary proteinase levels. J Periodontol 1999;70:1361-8.

18. Lindquist LW, Carlsson GE, Jemt T. Association between marginal bone loss around osseointegrated mandibular implants and smoking habits: a 10-year follow-up study. J Dent Res 1997;76:1667-74.

19. Morozumi T, Kubota T, Sato T, Okuda K, Yoshie H. Smoking cessation increases gingival blood flow and gingival crevicular fluid. J Clin Periodontol 2004;31:267-72.

20. Nair P, Sutherland G, Palmer RM, Wilson RF, Scott DA. Gingival bleeding on probing increases after quitting smoking. J Clin Periodontol 2003;30:435-7.

21. Nociti Jr FH, César-Neto JB, Carvalho MD, Sallum EA. Bone density around titanium implants may be influenced by intermittent cigarette smoke inhalation: a histometric study in rats. Int J Oral Maxillofac Implants 2002;17:347-2.

22. Nociti Jr FH, César-Neto JB, Carvalho MD, Sallum EA, Sallum AW. Intermittent cigarette smoke inhalation may affect bone volume around titanium implants in rats. J Periodontol 2002;73:982-7.

23. Peacock ME, Sutherland DE, Schuster GS, Brennan WA, O'Neal RB, Strong SL, et al. The effect of nicotine on reproduction and attachment of human gingival fibroblasts in vitro. J Periodontol 1993;64:658-65.

24. Stefani CM, Nogueira F, Sallum EA, de Toledo S, Sallum AW, Nociti Jr FH. Influence of nicotine administration on different implant surfaces: a histometric study in rabbits. J Periodontol 2002;73:206-12.

25. Syversen U, Nordsletten L, Falch JA, Madsen JE, Nilsen OG, Waldum HL. Effect of lifelong nicotine inhalation on bone mass and mechanical properties in female rat femurs. Calcif Tissue Int 1999;65:246-9.

26. Tomar SL, Asma S. Smoking-attributable periodontitis in the United States: findings from NHANES III. National Health and Nutrition Examination Survey. J Periodontol 2000;71:743-51.

27. Ward KD, Klesges RC. A meta-analysis of the effects of cigarette smoking on bone mineral density. Calcif Tissue Int 2001;68:259-70. 